\title{
Pandangan Etika Kristen tentang Berbusana bagi Wanita Kristen
}

\author{
Evi Prasti \\ Sekolah Tinggi Teologi Berita Hidup \\ hizkiapetra@gmail.com
}

\begin{abstract}
In dressed placement there are special situations that require the wearer to dress in formal situations, namely government agencies, schools, offices and worship. In a semi-formal or causal situation that is a semi-formal situation but there is a limit of politeness also in non-formal situations such as in the market, at home. This situation has no rules that bind it from the three situations we must be able to choose clothing according to the provisions of the event we are going to attend. Christian women's clothing must be different, because it manifests the person of the Lord Jesus the Great and holy so that the appearance of dressed in Christianity especially prioritizes God rather than appearance. Because God is holy and holy, in practice daily life glorifies God through our bodies. In a position as a student, the clothes that are used are dress that is polite, not sexy, does not wear a T-shirt, does not wear a tight shirt, mini skirt, transparent clothes but can choose clothes that are reasonable and appropriate in the campus situation.
\end{abstract}

Keywords: ethic of fashion, fashion, fashioning, Christian woman

\begin{abstract}
Abstrak: Dalam penempatan berbusana ada situasi khusus yang menuntut si pemakai berbusana sapan dalam situasi formal yaitu instansi pemerintahan, sekolah, kantor dan beribadah. Dalam situasi semi formal atau causal yaitu situasi setengah formal tetapi ada batas kesopanan juga dalam situasi non formal seperti di pasar, dirumah. Situasi ini tidak ada peraturan yang mengikatnya dari ketiga situasi tersebut kita harus dapat memilih busana sesuai ketentuan acara yang kita akan hadiri. Busana wanita Kristen harus berbeda, karena mewujudkan pribadi Tuhan Yesus yang Agung dan kudus sehingga penampilan dalam berbusana orang Kristen terlebih mengutamakan Tuhan dari pada penampilan. Sebab tuhan adalah suci dan kudus maka dalam praktek kehidupan sehari hari memuliakan Tuhan melalui tubuh kita. Dalam posisi sebagai mahasiswa maka busana yang dipakai adalah busana yang sopan, tidak seksi, tidak memakai kaos oblong,tidak memakai kaos ketat,rok mini, baju transparan melainkan dapat memilih busana yang wajar dan pantas dalam situasi kampus.
\end{abstract}

Kata Kunci: berbusana, busana, etika berbusana, wanita Kristen

\section{PENDAHULUAN}

Dalam setiap kehidupan memiliki perubahan baik dalam bidang teknologi maupun pola pikir manusia. Manusia selau ingin mencoba sesuatu yang baru sesuai dengan kemajuan zaman. Hal ini dapat dilihat melalui kebudayaan manusia pertama yaitu Adam dan Hawa, ketiaka ada di dalam taman Eden mereka merasa malu tidak mengenakan busana. Melihat awal mengunakan busana, maka fungsi dari dari berbusana adalah melindungi dari pengaruh alam sekitar misalnya: panas matahari, hujan, udara, dingin dan 
lain sebagainya. ${ }^{1}$ Ketika manusia belum meiliki alat yang canggih untuk membuat kain, pada zaman dahulu kain di buat dari bahan alam, seperti bahan kulit binatang, dari kulit kayu yang di proses seadanya tanpa alat modern melainkan menggunakan batu untuk memukul-mukul hingga kulit kayu atau kulit binatang itu menjadi lembaran yang digunakan untuk melilitkan bagian tubuh yang penting. ${ }^{2}$

Ketika model begitu berganti maka para perancang busana terus mengembangkan ide-idenya dalam menciptakan busana yang indah, menarik untuk diikuti perkembangannya, sehingga masyarakat dapat berbusana dengan menarik sesuai dengan waktu dan kesempatan yang diingini, terlebih perkembangan busana masa kini kemudahan-kemudahan dalam bidang konveksi akan semakin marak memenuhi selera pasar.

Dalam perkembangan dunia pertekstilan, secara khusus ahli dan perancang busana berusaha memberikan sesuatu yang menarik dengan menciptakan berbagai aksesori sebagai perlengkapannya. Ada bermacam aksesoris yang menjadi pelengkap dalam berbusana yaitu topi, jam, pita, bordiran, dan lain sebagainya.

\section{Etika dalam Perkembangan Busana}

Etika berbusana yang berlaku dalam masyarakat, hubungan etika dengan busana pandangan Etika mengenai perkembangan busana masa kini. Dalam kehidupan sehari hari manusia tidak lepas dari unsur-unsur etika, karena dalam segala kegiatan masyarakat selalu mengatakan atau menghubungkan segala sesuatu dengan etika. Misalnya etika makan, etika bertamu, etika berpakaian,etika berkomunikasi,etika masyarakat, dan lain lain. Abineno mengatakan bahwa istilah etika berasal dari kata Yunani "etos" yang memiliki dua arti yaitu tempat tinggal dan adat istiadat atau kebiasaan. ${ }^{3}$

Menurut Kamus Besar Bahasa Indonesia pengertian etika adalah "ilmu tentang apa yang bijak dan apa yang buruk dan tentang hak dan kewajiban moral. ${ }^{4}$ Istilah etika juga dipakai dalam berbagai hubungan dalam berbusana merupakan kebiasaan dalam kehidupan masyarakat, maka secara tidak sengaja atau tidak sadar etika berbusana juga berkembang dan sampai sekarang menjadi peraturan tidak tertulis dalam masyarakat.

Dalam etika terkandung moralitas yang memiliki arti kelakuan yang membentuk prinsip menentukan tindak tanduk yang benar atau salah." Ketika dunia ini mengalami perkembangan yang sangat pesat etika dan moral begitu diperhatikan oleh masyarakat sekarang ini. Dalam setiap kesempatan manusia memerlukan busana sebagai syarat kesopanan sebagai bukti bahwa manusia sudah memiliki peradapan. Peradaban adalah proses transformasi dan adaptasi. Hal ini berarti setelah manusia memiliki peradaban

\footnotetext{
${ }^{1}$ Tim penyusun Kamus Besar Bahasa Indonesia, “Pakaian” dalam Kamus Besar Bahasa Indonesia. Peny Anton Moeliono ( Jakarta: Balai Pustaka,2002),215.

${ }^{2}$ Pengetahuan Pakaian ( Jakarta: Depdikud SMK,1984), 1.

${ }^{3}$ Ch, Abineno, Sekitar Etika dan Soal Etis ( Jakarta: BPK Gunung Mulia,1994),2.

${ }^{4}$ Tim Penyususun Kamus Pusat Pembinaan dan pengembangan Bahasa"etika" dalam kamus Besar Bahasa Indonesia, peny.,Anton M, Moeliono( Jakarta:Balai Pustaka, 1990), 206.

${ }^{5}$ Dorthy I Marx New Morality (Bandung: Kalam hidup,1993), 9.
} 
proses penyesuaian diri terhadap lingkungan sekitar berjalan terus menerus untuk mengembangkan segala sesuatu menjadi indah dan bermanfaat bagi kelangsungan hidup manusia.

Menurut pandangan Kristen Etika adalah pandangan tentang manfaatnya peraturan peraturan dan tentang manfaat moral atau kesusilaan, erat dengan hubungan dengan pandangan hidup kita. Makluk yang memiliki moral hanya memiliki kebahagiaan yang sejati kalau ia hidup dalam kebenaran dan kesucian. ${ }^{6}$ Sebagai manusia yang taat kepada Tuhan, orang Kristen harus dapat menjadi saksi dalam setiap aspek kehidupan kita, karena kita hidup dalam lingkungan masyarakat yang sudah memiliki peradapan sehingga dalam bertindak harus benar benar sesuai dengan tuntutan yang bersifat positif. Setiap saat manusia diperhadapkan dengan pengambilaan keputusan secara etis sesuai dengan persoalan yang dighadapi, dalam hal ini sebagai orang Kristen perlu memiliki pertimbangan-pertimbangan yang sesuai dengan pandangan Allah karena setiap tingkah laku manusia tidak terlepas dari perkenalan kita akan Allah atau pengertian hukum-hukumNya dan perintah-Nya. Dan makhluk yang memiliki moral mampu melakukan yang benar sehingga mempunyai kebebasan untuk memilih. Makhluk yang memiliki moral hanya memperoleh kebahagiaan yang sejati kalau ia hidup dalam kebenaran dan kesucian. ${ }^{7}$

Masyarakat Indonesia dikenal sebagai masyarakat yang sopan dan berbudi pekerti yang baik. Dalam uraian ini penulis akan menguraikan mengenai etika yang berlaku dalammasyarakat. Masyarakat yang santun juga mempunyai etika bahwa setiap orang memiliki cara atau pendapat dalam menerapkan etika hidup sehari-hari, sebagai contoh budaya bangsa Indonesia yang memperhatikan seluruh sikap, baik tutur kata, tingkah laku dan aturan dalam masyarakat terlebih dari cara mengenakan busana. ${ }^{8}$ Sering kali orang menilai kebribadian seseorang melalui penampilan atau busana yang dikenakan.

Etika tidak dapat lepas dari kebudayaan yang dipegang oleh suatu kelompok atau lingkungan, maka kebanyakan orang yang mengutamakan etika sebagai prinsip hidup dalam segala bidang kehidupan. Masyarakat menilai bahwa dalam mengenakan busana harus sesuai dengan keadaan, kebudayakan, etiket, sopan santun. Norma kesusialaan agar terciptakan suatu bentuk pribadi yang menghargai lingkungannya.

Ketika manusia ingin mengunakan busana, manusia akan berfikir bahwa ia akan tampil semenarik mungkin. Sehingga ketika diperhatikan oleh orang lain akan terlihat indah. Pentingnya memperhatikan etika berbusana, supaya orang akan menilai kita lebih positif terhadap penampilan kita. Selama berabad-abad cara berpakaian orang selalu berubah sesuai dengan perkembangan busana yang disukai mmasyarakat, ketika etika sudah menjadi bagian dalam masyarakat. Secara tidak langsung segala tingkah laku seseorang harus sesuai dengan etika, seperti halnya pada Zaman Perjanjian Lama, orang sudah mengenal akan arti pentingnya etika berbusana. Mereka menggunakan pakaian

\footnotetext{
${ }^{6}$ Abineno, Sekitar etika, 14.

${ }^{7}$ Ibid.

${ }^{8}$ S.Djosodiarjo, Etika ( Pati: Mahabarata, 1952), 10
} 
"simlah" yang bertujuan untuk menutupi bagian tubuh, meskipun simlah ini digunakan untuk pakaian luar yang menyerupai selembar kain yang lebar dengan kerudung kepala. ${ }^{9}$

Hubungan etika dengan busana tidak terlalu terlihat, karena kita berbusana kurang banyak disebut dalam kehidupan masyarakat, tetapi etika dan busana tidak dapat dipisahkan karena dalam etika terkandung kebudayaan dalam peradapan manusia yang diwujudkan melalui busana sebagai syarat kesopanan, sedang busana tanpa etika akan menghasilkan penampilan yang menarik dan kurang pas sebagai contoh: dalam bekerja menggunkan busana yang digunakan di luar atau yang kurang sopan, agak sedikit terbuka. Dalam hal demikian etika dan busana tidak selau berhubungan dengan kesopanan, kesusilaan, ketepatan dalam berbagai situasi, melainkan bagaimana seseorang dapat menepatkan dirinya dengan busana yang dikenakan. Dalam etika ada dua bagian yang tidak dapat dipisahkan yaitu individu dan sosial karena dalam menentukan suatu keputusan etis, individu memerlukan lingkungan sosial, tentunya dalam etika berbusana lingkungan sosial juga ikut memberikan penilian, baik buruknya, sopan atau tidaknya, dan sebagainya. $^{10}$

Dalam menentukan busana di kehidupan sehari-hari atau dalam beraktivitas sehingga memberikan kesan yang menarik dan tidak terlepas dari unsur-unsur etika, seseorang harus memiliki prinsip yang benar dalam berbusana. Menurut Ratih "Dalam penampilan ada rumus yang dapat menentukan prinsip berbusana yang baik yaitu, dengan menerapkan prinsip: Who, When, Where, What, Why, dan How. ${ }^{11}$ Mengikuti prinsip ini memerlukan kepekaan dan fleksibilitas yang tinggi. Misalnya busana yang akan dikenakan juga sesuai dengan posisi atau jabatan seseorang dalam setiap pekerjaannya.

Busana yang memiliki unsur etika apabila busana yang digunakan sesuai dengan bentuk tubuh pemakai dan cara pemaduannya serasi tidak kontras dan dipadukan dengan sikap hidup yang penuh keramahan. ${ }^{12}$ Menilai cara berbusana tidak lepas dari karakter dari pemakainya , apa bila orang menggunakan busana dengan unsur unsur di dalam berbusana baik itu tekstur postur tubuh akan menambah keharmonisan di dalam diri pemakai sehingga menujukkan citra diri yang berwibawa. Dalam ceramah kesekrertarisan, di Jakarta artis dan model Titi Qadarsih memberikan pengarahan yaitu:

Sebagai seorang sekretaris harus dapat menunjukkan jati diri baik itu dalam berbusana dan bertutur kata. Ketika menggunakan busana alangkah baiknya mengombinasikan warna dengan baik dan seoarang sekertaris harus memperhatikan sikap atau cara duduk yang baik sehingga orang lain memberikan respon positif dan busana yang di gambar harus berpedoman kepada etika berbusana ${ }^{13}$

Pendapat ini memiliki arti bahwa dalam berbusana terdapat unsur-unsur etika yang harus diterapkan bagi setiap orang yang ingin berpenampilan rapi dan menarik dan memberi

\footnotetext{
${ }^{9}$ John stoot, Isu-isu Global ( jakarta: BPK Gunung Mulia, 1997), 14

${ }^{10}$ Ibid.

${ }^{11}$ Ratih Poeradisastra, Pandupadan Busana Pria ( Jakarta: Gramedia,2007), 14.

${ }^{12}$ N.I. Roeswoto, dan Sannynusi, Busana Pandupandan Modul Pengantar ( Jakarta: Proyek Peningkatan Pendididkan kejujuran Nonteknik,t.t), 12.

${ }^{13}$ Titi Qadarsih, "Sekertaris. Dalam Ceramah dan Pengarahan," Femina, 8 Mei 1995, 14
} 
kesan yang dapat diterima oleh masyarakat. Korelasi antara etika dan busana dalam kehidupanmasyarakat memiliki penilaian yang berbeda-beda terlebih sebagai orang yang percaya didalam mengenakan busana dalam gereja.

Hendaknya etika berbusana senantiasa diperhatikan dan terus diterapkan karena apabila berbusana tidak memperhatikan etika akan cepat mendapat respon yang kurang menarik bagi orang lain. Contohnya ketika memimpin ibadah, seorang pendeta mengunakan busana warna hem dengan pantalonnya kontras, maka secara tidak langsung kurang begitu fokus kepada pemberitaan firman Tuhannya, melainkan pandangan akan tertuju pada busana yang dikenakan dikarenakan kurang pas. Melalui busana dapat memberikan dorongan bagi setiap orang untuk memiliki penampilan yang baik dan dapat memilih model busana yang tidak sekedar mengikuti tred yang hanya sesaat saja melainkan dapat memilih model yang dapat mencerminkan pribadi yang beretika. ${ }^{14}$

Apabila ditinjau dari firman Tuhan mengenai hubungan etika busana ini terjadi sesudah manusia jatuh dalam dosa, sehingga manusia merasa malu tidak menggunakan busana karena perbedaan bentuk atonomi tubuh yang berbeda sehingga perasaan malu yang dimiliki manusia sejak awal memiliki hubungan dengan kesusilaan sehingga peristiwa ini menjadi awal terbentuknya busana. ${ }^{15}$ Hal ini membuktikan bahwa sejak awal manusia harus memegang prinsip prinsip etika dalam setiap aktivitas dalam kehidupan sehari hari. Setiap orang memerlukan busana dalam melakukan aktivitas sehati-hari. Sebelum memilih busana yang akan diguanakan alangkah baiknya, jika mau meneliti lebih dahulu busana yang akan dikenakan sehngga terciptalah busana yang serasi, sopan, tetapi memiliki nilai etika yang tinggi.

\section{Etika dengan Perkembangan Busana Masa Kini}

Perkembangan busana masa kini cukup beraneka ragam dan mode yang berjiwa muda dan mode yang sedang di gemari oleh masyarakat adalah mode yang berjiwa muda dan dapat dikatakan banyak bermuculan busana yang seksi dan modis. ${ }^{16}$ Pergeseran sopan santun sebagai akibat dari perkembangan zaman busana tidak lagi memperhatika etika. ${ }^{17}$ Hal ini dapat diartikan bahwa hubungan etika berbusana dalam perkembangan mode masa kini memiliki peran penting dalam masyarakat. Dalam pandangan orang jawa mengenai nilai etika dalam berbusana dirasakan sangat penting karena budaya yang masuk pertama kali dipengaruhui oleh budaya Islam yang berbusana dengan pakaian tertutup. Hal ini membuat penilaian mengenai perkembangan busana saat ini. Cenderung terbuka hanya menonjolkan segi keindahannya tanpa memperhatikan segi etikanya.

Namun ada sesuatu hal yang tidak harus berubah dalam diri manusia yaitu unsurunsur budaya dan etika yang harus tetap dilestarikan terlebih dalam cara berbusana yang

\footnotetext{
${ }^{14}$ Ibid, 32 .

${ }^{15}$ Wendi K, Ketika Model Memasuki Gereja ( Narawastu: Februari,2002), 3.

${ }^{16}$ Pekan Mode New York 2004" Minggu 28 september2003.

${ }^{17}$ Ibid., 31.
} 
baik meskipun model busana beraneka ragam. Alangkah baiknya kalau memilih busana yang sopan dan tidak meninggalkan fungsi serta tujuan berbusana.

\section{Kajian tentang Busana}

Tujuan berbusana yang menguraikan atau menjelaskan mengenai manfaat busana untuk melindungi tubuh, memperindah penampilan, menutupi kekurangan dari bagian tubuh. Pemilihan busana yang tepat yang disesuaikan dengan ukuran badaan disesuaikan dengan norma dan kesopanan disesuaikan dengan situasi dan kodisi, busana yang pantas bagi wanita Kristen.

Busana adalah kain yang yang di olah menjadi pakaian yang dikenakan oleh manusia yang bertujuan untuk menutupi bagian bagian tubuh dari cuaca disekitar kita atau pakaian lengkap yang indah indah. ${ }^{18}$ Dalam zaman Perjanjian Lama "Pakaian terpenting agaknya adalah semacam cawat atau kain yang pajang atau pendek penutup tubuh, sehelai kain untuk bagian atas mantel, ikat pinggang, pengikat kepala, tudung dan sandal. ${ }^{19}$ Dalam kehidupan sehari hari-hari, mengatur penampilan dari merupakan salah satu awal yang dilalui hampir setiap orang, sebelum melakukan aktifitas lainnya. Untuk dapat berbusana yang baik seseorang harus mengerti dengan jelas akan busana yang akan digunakan dalam situasi formal atau non formal adapun pengertian dari busana formal dan non formal adalah:

Arti kata formal adalah "resmi" atau tempat tempat yang memiliki arti penting seperti sekolahan, instansi pemerintahan, kantor, dan lain lain. Seperti yang telah dijelaskan di atas bahwa seseorang berbusana ditentukan oleh situasi yang mendukung dalam beraktivitas. ${ }^{20}$

Dalam melakukan kegiatan di kantor atau tempat yang resmi kita harus dapat memilih busana yang sopan, rapi, menarik, bersih, warna dipilih untuk tidak mencolok, tidak menggangu akitivitas si pemakai. Syarat di atas memang tidak mutlak harus ditaati semua orang karena dalam berbusana adalah pribadi masing masing orang, yang tidak dapat diatur oleh orang lain, namun adalah baiknya apabila penampilan dalam situasi formal, busana yang digunakan dapat memberi kesan menarik bagi orang lain. Agar memiliki penampilan yang menarik ada beberapa hal yang diperhatikan misalnya waktu siang atau malam untuk lebih jelasnya ada bagian dalam berbusana:

\section{Busana Non Formal}

Busana non formal adalah busana yang digunakan dalam kehidupan sehari hari yang tidak resmi. ${ }^{21}$ Misalnya di rumah, pasar, dapur, dan lain sebagainya. Busana non formal ini memiliki sifat santai dan bebas tidak ditentukan modelnya, jenis bahannya,kesempatannya, namun tetap sopan dan menarik. Busana non formal dapat digunakan di mana saja tidak

\footnotetext{
${ }^{18}$ Tim Penyusun Pusat Pembinaan dan Penggembangan Bahasa "Busana" dalam Kamus Besar Bahasa Indonesia, Pen., Anton M., Moeliono ( Jakarta: Balai Pustaka 2002), 146.

${ }^{19}$ Ibid, 148.

${ }^{20}$ Tim Penyusun Pusat Pembinaan dan Pengembngan Bahasa "Resmi" dalam Kamus Besar Bahasa Indonesia, 476.

${ }^{21}$ Ibid, 146.
} 
ada batas-batas yang ditentukan, asalkan masih sesuai dengan etika masyarakat. Meskipun busana non formal dapat digunakan di mana ada beberapa hal yang harus diperhatikan berkenaan dengan sifat busana dan jenis bahan yang harus dipilih. Seperti halnya, warna yang pantas tidak mencolok, hiasan tidak terlalu berlebihan, jenis bahan yang digunakan dapat meresapi keringat, busana model sederhana tapi menarik atau indah.

\section{Busana Semi Formal}

Ada beberapa busana semi formal yang digunakan dalam suasana kerja karena tuntutan profesi yang mengharuskan berbusana semi formal yaitu busana bagi pekerja di proyek-proyek yang mengharuskan berbusana semi formal yaitu busana bagi pekerja. Busana semi formal busana ini digunakan bagi para pekerja yang ada diluar kantor atau pekerjaannya yang terjun dilapangan. Maka manusia selalu mengembangkan bentuk busana yang dapat dikelompok kelompokan dalam jenis keadaan orang lebih memilih busana yang santai seperti kaos, celana, streat yang tidak resmi sehingga orang agak bergerak bebas tidak terikat dengan busana yang dipakainya. Setiap kesempatan yang akan kita lakukan, busana yang dikenakan harus dapat memberikan kesan indah sebagai bukti bahwa busana itu dapat merubah penampilan seseorang terlihat menarik. Dalam pemilihan busana selain ditentukan dengan situasi dan waktu pemilihan busana yang tepat.

\section{Fungsi Busana}

Manusia berbusana bertujuan untuk memperindah penampilan karena penampilannya yang bersih dengan busana yang serasi merupakan salah satu bagaimana keperibadian seseorang dinilai oleh orang lai. Dalam kehidupan manusia tidak lepas dari kegiatan atau kesibukkan yang dilakukan maka manusia harus mengunakan busana. Manfaat berbusana yang bertujuan melindungi tubuh, busana juga dapat memperindah penampilan apabila dikenakan dengan tepat, busana juga memiliki fungsi untuk menutupi kekurangan dari bagian tubuh.

Pertama, berbusana bermanfaat melindungi tubuh. Ketika manusia mengetahui manfaat dan keuntungan mengenakan busana maka manusia menciptakan dasar busana sesuai dengan iklim atau keadaan yang ada disekitarnya agar busana yang akan digunakan sesuai dengan jenis-jenis kain yang akan digunakan, misalnya kain lenan adalah jenis kain yang akan digunakan; misalnya kain lenan adalah jenis kain yang dibuat dari tanaman rammi. Lenan adalah kain yang serba guna yang dapat ditenun menjadi kain kasat dan tebal atau amat halus dan lembut dan sangat cocok untuk daerah yang beriklim panas dan sedang. Ketika busana sudah menjadi bagaian dari kehidupan setiap orang, pada zaman ini banyak terdapat model-model busana yang sudah beranaeka ragam.

Setiap orang sudah merasakan betapa pentingnya busana bagi tubuh dan alangkah baiknya apa bila busana yang dipilih dapat menunjukkan keperibadian orang yang memakainya, maksudnya bahwa setiap busana dikenakaan sesuai dengan fungsi dan kegunaannya akan terlihat lebih pantas.

Manfaat kedua adalah dapat memperindah penampilan. Setiap orang menginginkan keindahan dalam setiap aspek kehidupannya, karena dengan keindahan hidup akan terasa 
nyaman dan memiliki cinta rasa tinggi. Demikian juga dalam berbusana, keindahan juga terdapat dalam cara seseorang mengatur busana yang akan digunakan dengan memadukan hal-hal yang bersifat menarik. Selain bermanfaat melindungi tubuh, busana dapat berfungsi memperindah penampilan.

Dengan busana seseorang akan merasakan bahwa dirinya lebih baik, lebih pantas, lebih cantik atau lebih tampan. Fungsi busana untuk memperindah atau menghias diri semakin meningkat. Hal itu terwujud pada cara pertama membentuk busana melalui seni potong kedua, pengelolahan bahan busana sedemikian rupa sehingga terciptalah bahan yang indah dengan segala sifatnya, dapat dipakai untuk memperindah tubuh, ketiga, menciptakan pola serta ornamen hiasan busana, keempat mengolah bahan usaha sedemikian rupa sehingga terciptalah bahan yang indah dengan segala sifatnya, kelima, berbagai jenis warna dari bahan alamiah atau sinteses. ${ }^{22}$

Dalam perkembangan busana telah berkembang cukup pesat sehingga manfaatnya telah dirasakan oleh masyarakat sebagai memperindah atau mempercantik penampilan sehari hari. Dalam pemilihan keindahan dan keserasian berbusana dapat dibagi menjadi dua dalam pemilihan warna dan penggunaan aksesori sehingga dihasilkan penampilan yang penuh dengan keserasian.

\section{Menutupi Kekurangan dari Bagian Tubuh}

Untuk meneliti bagian tubuh yang memiliki kekurangan, ada cara mudah untuk mengetahuinya, Pertama, berdirilah di depan cermin, amati refleksi badan yang ada di cermin dengan sesakma. Kedua, amati secara keseluruhan kemudian berbagian dari atas sampai pinggang, lalu dilajutkan dari pinggang hingga kebawah. ${ }^{23}$ Hal demikian adalah salah satu cara untuk menerima atau mengetahui bagian yang kurang. Kita tidak perlu cemas atau kwatir. Kekurangan tubuh ditutupi dengan cara mengkamuflasekannya lewat busana.

Dalam tubuh manusia terdapat kekurangan yang satu dengan yang lainnya tidak sama, cara menutupi bentuk tubuh yang kurang dengan cara menitik beratkan pada aksen yang lebih indah dalam tubuh sehingga titik perhatian orang lebih kepada hal-hal yang positif. Hal ini berarti tubuh yang memiliki kekurangan dapat ditutupi dengan busana yang memiliki desain yang malah menambah buruk tubuh kita. Masing-masing orang memiliki tipe tubuh yang terutama wanita sebagai pedoman dalam menata penampilan sehari-hari agar terlihat sesuai dengan fungsi dan tujuan berbusana.

\section{Pemilihan Busana yang Tepat}

Setelah mengetahui mengenai fungsi dari busana dalam pembahasan ini akan menguraikan mengenai pemilihan busana yang tepat. Untuk mendapatkan busana yang baik dibutuhkan pemilihan yang selektif dari sipemakai, arena dari rutinitas dan aktifitas seseorang dengan yang lain berbeda. Penyesuaian dalam pemilihan busana juga memiliki

\footnotetext{
${ }^{22}$ Pengetahuan Pakaian ( Jakarta: Departemen Pendidikan dan Kebudayaan Pendidikan Menengah Kejujuran,1984), 10.

${ }^{23}$ Ibid.
} 
peran masing-masing membutuhkan busana yana semi cansual setengah resmi namun tetap memenuhui syarat dalam pekerjaannya. ${ }^{24}$ Untuk memenuhui syarat pemilihan busana yang tepat ada beberapa hal yang memperhatikan yaitu busana yang sesuai dengan ukuran badan, busana harus sesuai dengan norma dan kesopanan, dalam pemakaian busana harus mengerti situasi kondisi.

Busana yang pantas bagi wanita Kristen harus dipertimbangkan. Dalam hal ini akan dibahas mengenai busana yang pantas bagi wanita Kristen, seperti yang telah dijelaskan pada bagian sebelumnya mengenai busana yang berkembang pada saat ini yang hanya memperlihatkan segi estikanya saja tanpa memperhatikan sudut etikanya, maka sebagai wanita Kristen cara berbusana sangatlah penting diperhatiakan, karena setiap gerak langkah seorang diperhatikan orang lain dan busana yang dikenakan kurang pantas maka orang lain akan memberi penilaian yang kurang baik terhadap si pemakai. Surat Petrus dalam terjemahan lama mengatakan: "Janganlah kamu menghias dirimu yang lahir dengan rambut berajam dan memakai barang emas, atau memakai pakaian yang indah-indah. Melainkan sifat yang baik pada batinnya...yaitu perangai yang lemah lembut dan pendiam yang besar harganya dimata Allah..." (1 Pet 3:2-5). Ayat ini memiliki pengertian bahwa sebagai wanita kristen harus dapat memilih perhiasan atau pakaian yang dunia tawarkan dalam berbagai bentuk yang indah dan mahal mahal tetapi bagai hal yang penting bagi wanita Kristen yaitu pribadi yang taat kepada Tuhan.

Sebagai umat Kristen dalam mengenakan busana dan ibadah alangkah baiknya diperhatikan karena menurut pandangan penulis bahwa orang lain yang bukan menggunakan busana yang bersih, indah, terlebih sopan. Demikian juga orang Kristen selalu menjaga sikap atau berbusana ketika menghadap Tuhan, "Busana dan penampilan dapat dianggap sebagai cermin kepribadian, maka kerapian dan berbusana dan penampilan harus menjadi sasaran, karena sebagai umat pilihan Tuhan harus dapat menunjukkan bahwa dirinya saksi Kristus. Memuliakan Allah dengan tubuh, mengandung pengertian bahwa dalam segala aspek kehidupan manusia baik itu tutur kata, tingkah laku dan dalam penampilan harus dapat memperhatikan atau menggunakan dengan hati-hati dan semuanya ditunjukan untuk kemuliaan Tuhan.

Pakaian wanita haruslah sopan, tertib dan mempunyai cita rasa yang baik dalam Alkitab terjemahan lama dituliskan "Demikian juga hendaknya segala perempuan menghiasi dirinya dengan memakai pakaian yang patut, serta dengan sopan dan siuman, atau mutiara yang berharga" (I Tim. 2:9). Jadi pengertian mengenai berbusana yang pantas bagi wanita Kristen merupakan berbusana harus benar benar diperhatikan terlebih dalam melayani atau sebagai pemimpin jemaat, dalam penampilan sering diperhatikan oleh jemaat. Misalnya: dalam berkhotbah seorang pendeta mengenakan busana yang sobek atau perpaduan warna kurang tepat, jemaat akan memberi penilaian yang tidak baik atau dengan kata lain menjadi batu sandungan.

\footnotetext{
${ }^{24}$ Jati Pratiwi, Pola Dasar dan pecah Pola Busana (Yogyakarta: Kanisius, 2001), 2.
} 
Sebagai wanita Kristen perlu untuk mengetahui bahwa orang percaya adalah penyembah-penyebah Allah, yang diciptakan oleh Tuhan Yesus Kristus untuk melakukan perbuatan perbuatan baik (Ef. 2:20; Tit. 2:14), Wanita itu boleh memakai pakaian yang indah namun apa yang dipakainya tersebut untuk menyatakan bahwa mereka kenal dengan Tuhan Yesus Kristus dan ingin memuliakanNya.

\section{PEMBAHASAN}

\section{Penerapan Etika Berbusana bagi Wanita Kristen Masa Kini}

Dalam berbusana terdapat perbedaan mencolok antara laki-laki dan perempuan, perempuan biasanya sangat memperhatikan dan menjaga penampilannya ada satu perancang busana perempuan yang bernama Yves Saint Laurent dari Paris. Yang berpendapat bahwa, busana sangat berpengaruh dalam transformasi sebuah zaman. ${ }^{25}$ Seperti yang telah dijelaskan bahwa fungsi dan tujuan berbusana adalah melindungi tubuh dan memperindah tubuh. Kebiasaan yang dimiliki oleh wanita Kristen adalah perhiasan rohani setiap seseorang memiliki ciri khas masing masing terlebih melihat perkembangan busana yang semakin beraneka ragam membuat orang ingin penampilan menawan.

Dalam 1 Petrus 3:3-4 Firman Tuhan ini menunjukkan bahwa pengenalan kepada Tuhan jauh lebih penting dari pada penampilan tubuh karena "kecantikan dalam penampilan dapat pundar tetapi apa yang ada dalam hati tidak akan lekang dimakan waktu. Penampilan yang sesungguhnya adalah penampilan yang saling berhubungan antara iman dan berbuatan penampilan bagi wanita Kristen adalah pertama wanita Kristen harus memiliki hubungan pribadi dalam saat teduh, kedua wanita kristen yang mau mengasihi orang lain dengan segenap hati, ketiga menjadi wanita Kristen yang tidak terbawa arus perkembangan zaman terlebih perkembangan mode.

Penerapan praktis berbusana dapat dilakukan antara lain:

- Penerapan sebagai mahasiswa di kampus

- Penerapan sebagai Hamba Tuhan di pelayanan

- Penerapan sebagai Jemaat secara umum

- Penerapan di masyarakat

Jadi wanita yang menjadi penerang dunia ini, dalam segala kehidupan hendaklah Firman Tuhan menjadi ladasan terutama bagi wanita dan dalam bersosialisasi dengan masyarakat peranan etika juga dibutuhkan sebagai alat pengukur baik pribadi dan masyarakat.

\section{KESIMPULAN}

Berdasarkan pembahasan diatas maka dapat disimpulkan sebagai berikut: Setiap orang dalam kehidupan sehari hari memerlukan busana agar penampilannya menarik dan keberadaan berbusana telah dirasakan manfaatnya bagi masyarakat akan tetapi proses perkembangannya busana berkembang pesat yang dahulu manusia melum mengerti arti dan fungsi dari berbusana kini orang sudah memerlukan busana. Secara umum sikap dan perilaku manusia tidak terlepas dari penilaian orang, sebagai wanita yang berharga dimata

\footnotetext{
${ }^{25}$ Wendi K. Ketika Mode Masuk Gereja (Narwastu, February, 2002), 31.
} 
Tuhan, selalu memperhatikan etika dan norma-norma yang berlaku dalam masyarakat yang memiliki kebudayaan dan adat istiadat. Sebagai orang Kristen harus mempertimbangkan etika Kristen yang berhubungan dengan dasar-dasar Kebenaran Firman Tuhan.

Mengikuti trend atau kemajuan zaman adalah hak dan kebebasan bagi setiap orang dan tidak terkecuali juga bagi orang Kristen, tetapi kebebasan yang dimiliki oleh orang Kristen bukanlah kebebasan tanpa batas. Sebab dalam penempatannya orang Kristen perlu mempertimbangkan dengan kebenaran Firman Tuhan dan juga norma-norma yang berlaku dalam masyarakat. Tujuannya adalah supaya melalui penampilan, orang lain bisa melihatnya sebagai wanita yang mengenal Kristus. Selain itu juga supaya karakter Kristus yang mulia tetap terpilihara dengan baik karena penampilan yang baik pula. Dalam menempatan berbusana ada situasi khusus yang menuntut si pemakai berbusana sopan dalam situasi formal yaitu di instasi pemerintahan, sekolah, kantor dan beribadah. Dalam situasi semi formal atau casual yaitu situasi setengah formal tetapi ada batas kesopanan juga dalam situasi non formal seperti di rumah, pasar. Situasi ini tidak ada peraturan yang mengikatnya dari ketiga situasi tersebut kita harus dapat memilih busana sesuai ketentuan acara yang kita hadiri.

Busana Kristen harus berbeda karena mewujudkan pribadi Tuhan Yesus yang Agung dan kudus sehingga penampilan dalam berbusana Kristen terlebih dahulu mengutamakan Tuhan dari pada penampilan. Sebab Tuhan adalah suci dan kudus maka dalam praktek kehidupan sehari hari memuliakan Tuhan melalui tubuh kita. Dalam posisi sebagai mahasiwa busana yang dipakai adalah busana yang sopan, tidak seksi,tidak memakai kaos oblong, tidak memakai kaos ketat rok mini, baju transparan, melainkan dapat memilih busana yang wajar dan pantas dalam situasi kampus.

Bagi wanita Kristen diharapkan memiliki sikap hati untuk selalu mengutamakan hubungan pribadi dengan Tuhan karena penampilan yang mengikuti perkembangan dunia tidak akan memberikan kepuasan yang maksimal, namun dapat membawa dampak yang tidak baik sehingga menjadi wanita yang konsumutif. Sebagai wanita yang dikendalikan oleh Kristus dalam setiap hidupnya bukan untuk dirinya sendiri melainkan untuk kemuliaan Tuhan dan selalu menghadirkan kesopanan dalam cara berbusananya.

Menempatkan diri dengan tepat dalam cara berbusana akan sangat bijaksana sehingga penampilan yang di inginkan akan lebih indah terlebih penampilan yang tidak pernah habis dimakan waktu yaitu memiliki iman yang dapat menjadi teladan bagi banyak orang. Sehingga hidup ini tetap memiliki sikap yang memuliakan Tuhan dalam penampilan yang sopan, indah dan menarik dan melalui penampilan yang baik secara langsung telah memuliakan Tuhan melalui penampilannya. 


\section{REFERENSI}

Abineno.J.Ch. Etika dan Soal-Soal etis. Jakarta:BPK Gunung Mulia 1994.

Budiman, Yoyok. Anda dan Gaya Busana. Jakarta, Gramedia, 2000.

Collum, Fiona M. Kecatikan Bagi seorang Wanita, surat Kabar Suara Merdeka. 21 april 1990.

Depdiknas, Pembuatan Busana Wanita dan Anak Harian Kompas. Jakarta september 2003.

Getz, Gene A. Citra Wanita Kristen. Jakarta: BPK Gunung Mulia,1994.

Hefley, Morti. Gadis Idaman. Bandung: Yayasan Kalam hidup t.t.

Kusuma Wardani, Reni. Pedoman Menata Gaya Busana. Jakarta: Gramedia, 2001.

Pratiwi ,Djati. Pola dasar Pecah Pola Busana. Yogyakarta: Kanisius, 2001.

Putera, Phil. Eka Dharma. Etika Sederhana Untuk semua. Jakarta: BPK Gunung Mulia 1992.

Stoot, john Isu-Isu Global. Jakarta: BPK Gunung Mulia, 1997.

Verkuil, J. Etika Kristen Kebudayaan. Jakarta: BPK Gunung Mulia, 1989. 